\title{
EFFECTS OF FOUNDATION CONCRETE SLABS IN PREVENTING ATTACK OF SUBTERRANEAN TERMITE PSAMMOTERMES HYBOSTOMA (DESNEUX) (ISOPTERA: RHINOTERMITIDAE) TO WOODEN BOARDS
}

\author{
AHMED, H.M. \\ Wood borers and termite Department, Plant protection Research Institute, ARC, \\ Dokki, Giza.
}

(Manuscript received 29 January 2012)

\begin{abstract}
A three successive years (2009 -2011) study was conducted to estimate the effects of foundation concrete slabs diversity in prevention of subterranean termite attack on wooden boards. Sixteen foundation concrete slabs were constructed inside a $600 \mathrm{~m}^{2}$ bungalow building, surrounded with fencing from hollow sand Crete blocks. Four groups of slabs were constructed, a- sand only, b- bush gravel, cmanually mixed crushed granite, and $d$ - mechanically mixed crushed granite Data showed that, the fourth group of foundation concrete slabs had 100 percent prevention of termite penetration, followed by the third group which showed high resistance to subterranean termite penetration. The second group of slabs had limited resistance to subterranean termite penetration, while the first group had no resistance to prevent subterranean termite penetration.
\end{abstract}

Keywords: Wood boards, concrete slabs, subterranean termite.

\section{INTRODUCTION}

Termites are divided into two major types, the dry wood type, which is capable of flying, and the subterranean type. Subterranean termites are social insects that live in societies of which members are, mostly, immature individuals. Their colonies, are formidable, being formed of thousands to millions of delicate soft bodied termites. In nature, subterranean termites are closely associated with the soil habitat where they tunnel to locate water and food (e.g., wood, fallen logs, and other cellulose- containing materials). (Daniel et. al., 2009). Termites excavate galleries through their food of which they consume. They conceal their workings and can completely honeycomb wood by feeding along the grain and following the softer spring wood, leaving little more than a thin wooden exterior. Subterranean termites construct aboveground earthen runways (shelter tubes) that protect them from the drying effects of air as well as from natural enemies, such as ants. Termites are very susceptible to desiccation, their life is dependent upon moisture sources. It is usual for flying termites to enter the end grain of untreated timber and build up a colony from 
inside, finally devouring all the interior wood and leaving only a thin skin behind.(Ahmed 1997). Some subterranean termites, operate from a central colony or nest and travel in search of food. These nests sometimes achieve great size and house millions of creatures (Beal, 1979). The paths to food are concealed where possible, otherwise a cover of tunnel is constructed. Subterranean termites normally construct their tunnel through the holes of hollow blocks to the top of the building, and finally to the wooden boards, (Anonymous 1976).To prevent subterranean termites from rising out of the ground into the building, two methods are generally used, a- mechanical barriers and b- insecticides. (Hadi, et. al., 2005).The mechanical barrier constitutes the construction of concrete slab on the foundation walls with minimum thickness of $100 \mathrm{~mm}$. This slab provides an obstacle for subterranean termites to construct their tunnel through the hole of hollow blocks. Subterranean termite, Psammotermes hybostoma (Desneux) (Fam. Rhinotermitidae) is considered to have a great economic importance in Egypt. It causes a great damage to the wooden boards and rural buildings constructed with mud bricks as well as furniture and farmed wood within new buildings (Ahmed, 2008). This subterranean termite species are widely dispersed allover the two sides of the River Nile and all Oases in both Eastern and Western deserts (Rizk et al. 1985). In residential buildings, the most commonly used materials for roofing systems are timber for the roofs and corrugated iron or long span aluminum sheets (Olanitori, 2006). As important as it is, the wooden boards are also the component of the buildings that are mostly abused and subjected to agents of degradation (Mijinyawa et. al., 2006). Some of the agents of degradation of wooden boards are the wood borers and subterranean termites. Aswan governorate is one of the most infested localities with subterranean termites. (Abdel-Wahab et al 1983). So, the present investigation is an attempt to study, the used of foundation concrete slabs diversity to prevent subterranean termites attack on wooden boards under Aswan conditions.

\section{MATERIALS AND METHODS}

The materials used for this work were, sand, bush-gravel, crushed granite, cement, water and powered concrete mixer. Sixteen foundation concrete slabs were constructed inside a $600 \mathrm{~m} 2$ bungalow building surrounded with fencing hollow sand Crete blocks and located in El-Gazera region Aswan Governorate. Slabs were investigated for capability to prevent subterranean termites attack to wooden boards for three successive years (2009-2011). Slabs were poured inside the wooden squares with dimensions $(1 \mathrm{~m} \times 1 \mathrm{~m})$ and $30 \mathrm{~cm}$. height on the infested soil. The sixteen 
concrete slabs were divided into four groups, depending on the provision of concrete slab, the type of gravel and mode of concrete mixing. The four groups of concrete slabs were, a- manually mixed, sand and cement , b- manually mixed bush-gravel, cmanually mixed crushed granite and $d$ - mechanically mixed. crushed granite. The mixing ratio of concrete for all the four groups was 1:2:4.(sand, gravel or granite and cement), respectively. Inspection of the wooden boards of the sixteen foundation concrete slabs were carried out every sixth months for a duration of thirty sixth months.

\section{RESULTS AND DISCUSSION}

According to table (1), for the first sixth months, the inspection indicated that there was no sign or traces of subterranean termite attack on the wooden boards of any of the sixteen foundation concrete slabs. The second inspection (carried out after twelve months) in December2009, showed traces of subterranean termite attack on the wooden boards of the first group of foundation concrete slabs (Fig.1).No traces of subterranean termite attack were noticed in the remaining three groups of foundation concrete slabs. The third inspection was carried out after eighteen months in (June2010), the effects of the subterranean termite attack on the wooden boards of the first group of slabs was noticed on the entire wooden boards. For the remaining groups slabs, no sign or traces of termite attack was noticed on the fourth group, while, in the second and third groups, termite attack could be noticed, with limited traces. With the fourth inspection, after twenty four months in (December 2010), termite attack was noticed on the second group of foundation concrete slabs, with limited traces. No sign or traces of termite attack was noticed on the third and fourth groups. The fifth and sixth inspections, were carried out in (June and December 2011), no traces of subterranean termite attack was noticed in all the groups of foundation concrete slabs except the first group, which showed termites attack to the wooden boards. Data obtained in table (2) revealed that, the maximum number of termites was 1438 individuals in the fourth inspection while, the least one was zero in the first inspection. The maximum number of tunnels was 28 in the six inspection while the least one was zero in the first inspection .

Data showed that, numbers of tunnels were increased gradually start from the third inspection until the late inspection of experiment. From the mentioned results it could be stated that, foundation slabs, constructed from mechanically mixed crushed granite, has $100 \%$ proof against subterranean termites, whereas the foundation slab constructed from manually mixed granite did not have full proof 
against subterranean termites. The foundation slab constructed from bush-gravel has limited proof, whereas foundation slab of manually mixed sand have no resistance against the subterranean termites. Ebeling \& Pence (1957) suggested a non-chemical beamer alternative when they discovered that beamers consisting of sand particles ranging in size from 10-16 mesh (equivalent to particles of $1.2-1.7 \mathrm{~mm}$ in diameter) were not penetrated by the western subterranean termite, Reticulitermes hesperus Banks .

Their observation indicated that the particles were too large for termites to displace with their mandibles, yet were small enough so termites could not maneuver between them. Because of the availability of inexpensive and effective soil termiticides, their discovery had been overlooked until the mid-'80s when Tamashiro et al. (1987) confirmed that these results could be applied to the Formosan subterranean termite, Coptotermes formosanus Shiraki. Furthermore, Smith and Rust (1990) found that $R$. hesperus did not penetrate beamers consisting of particles of 820 mesh (0.85-2.36 mm diam.). In this investigation, it could be recommended that in the areas which are located in El-Gazera region, Aswan Governorate, to prevent subterranean termite attacks, foundation slabs should be constructed to all buildings using mechanically mixed. crushed granite.

Table 1. The wooden board inspections at six monthly intervals.

\begin{tabular}{|c|c|c|c|c|c|c|}
\hline \multirow[t]{2}{*}{ Groups } & \multicolumn{6}{|c|}{ Inspections } \\
\hline & 1st & 2nd & 3rd & $4^{\text {th }}$ & $5^{\text {th }}$ & 6th \\
\hline Group I & No traces & Traces & Traces & Traces & Traces & Traces \\
\hline Group II & No traces & No traces & $\begin{array}{l}\text { Limited } \\
\text { traces }\end{array}$ & $\begin{array}{l}\text { Limited } \\
\text { traces }\end{array}$ & No traces & No traces \\
\hline Group III & No traces & No traces & $\begin{array}{l}\text { Limited } \\
\text { traces }\end{array}$ & No traces & No traces & No traces \\
\hline Group IV & No traces & No traces & No traces & No traces & No traces & No traces \\
\hline
\end{tabular}

I Foundation concrete slabs constructed from sand only

II- Foundation concrete slab constructed from bush gravel

III- Foundation slabs constructed with manually mixed crushed granite.

IV-Foundation concrete slab constructed from mechanically mixed crushed granite. 


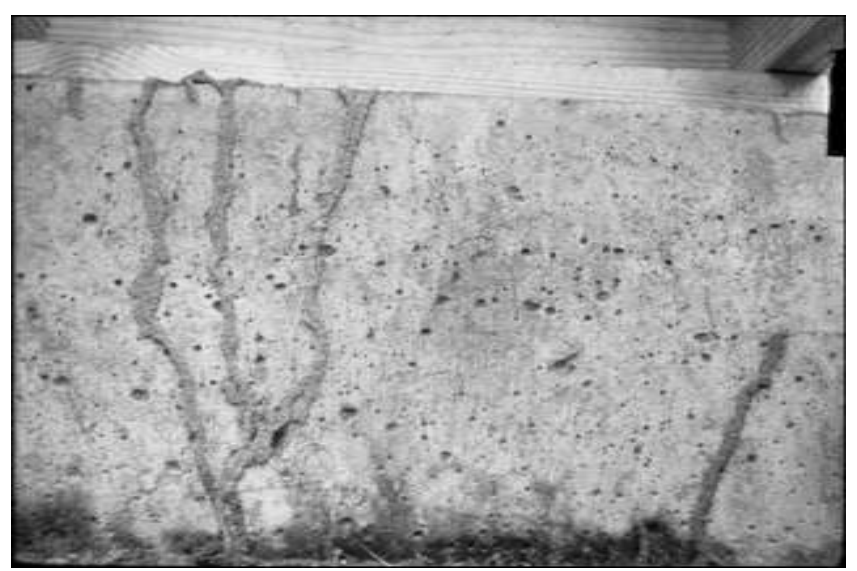

Fig. 1. Traces (mud tubes) of subterranean termite penetrated the foundation concrete slabs constructed from sand only.

Table 2. Tunneling numbers and termite individuals Psammotermes hybostoma (Desneux) at six month intervals.

\begin{tabular}{|c|c|c|c|c|c|c|c|}
\hline \multirow{4}{*}{$\begin{array}{l}\text { Inspections } \\
1^{\text {st }}\end{array}$} & \multirow{2}{*}{\multicolumn{2}{|c|}{$\begin{array}{c}\text { Tunneling and foragers } \\
\text { activity }\end{array}$}} & \multicolumn{5}{|c|}{ Groups } \\
\hline & & & \multirow{2}{*}{$\mathbf{I}$} & \multirow{2}{*}{ II } & \multirow{2}{*}{$\begin{array}{r}\text { III } \\
0\end{array}$} & \multirow{2}{*}{ IV } & \multirow{2}{*}{$\begin{array}{c}\text { Total } \\
0 \\
\end{array}$} \\
\hline & Numbers & Termites & & & & & \\
\hline & & Tunnels & 0 & 0 & 0 & 0 & 0 \\
\hline \multirow[t]{2}{*}{$2^{\text {nd }}$} & \multirow[t]{2}{*}{ Numbers } & Termites & 285 & 0 & 0 & 0 & 285 \\
\hline & & Tunnels & 3 & 0 & 0 & 0 & 3 \\
\hline \multirow[t]{2}{*}{$3^{\text {rd }}$} & \multirow[t]{2}{*}{ Numbers } & Termites & 456 & 126 & 79 & 0 & 661 \\
\hline & & Tunnels & 9 & 1 & 1 & 0 & 11 \\
\hline \multirow[t]{2}{*}{$4^{\text {th }}$} & \multirow[t]{2}{*}{ Numbers } & Termites & 1184 & 254 & 0 & 0 & 1438 \\
\hline & & Tunnels & 13 & 2 & 0 & 0 & 15 \\
\hline \multirow[t]{2}{*}{$5^{\text {th }}$} & \multirow[t]{2}{*}{ Numbers } & Termites & 1298 & 0 & 0 & 0 & 1298 \\
\hline & & Tunnels & 21 & 0 & 0 & 0 & 21 \\
\hline \multirow[t]{2}{*}{$6^{\text {th }}$} & \multirow[t]{2}{*}{ Numbers } & Termites & 1348 & 0 & 0 & 0 & 1348 \\
\hline & & Tunnels & 28 & 0 & 0 & 0 & 28 \\
\hline
\end{tabular}




\section{REFERENCES}

1. Abdel- Wahab, M.A., M.R., Rizk, M.H., Hussein, T.K., Abdel-Raof and M.S. ELTaib. 1983. Surface activity of sand termite Psammotermes hybostoma (Desneux) in Asswan. Assuit, J. Agric. Sci. 14 (3): 99-108.

2. Ahmed, H.M. 1997. Ecological studies and control of harvester subterranean termites Anacanthotermes ochraceus (Burmesiter) at Fayoum Governorate. Ph.

D. Thesis Fac. Agric. Fayoum, Cairo University pp.77

3. Ahmed, H.M. 2008. Distribution and damage assessment of subterranean termites with refrence to foraging behaviour and population fluctuation at El Giza Governorate. Alx. J. Res. 53 (1) 55 - 62.

4. Anonymous. 1976. Termites and tropical building overseas building Knots No. 170, pp. 1-16 building. Research Station Garston Watford, UK. J. Econ. Entomol. 68 (4): 351-361.

5. Beal, R.H. 1979. Preventing termite attack by adding insecticides to particle board, hard board and plywood adhesive in U.S.A. Forst Product Journal, 29 (12): 29-34. Rev. Appl. Entomol., 75: 312-321.

6. Daniel R. S., C.J. Susan and T. F. Brian. 2009. Biology of subterranean termites in the eastern United States. Bulletin 1209 Reviewed March 2009, PP.1-8.

7. Ebeling W. and R. J. Pence. 1957. Relation of particle size of the penetration of subterranean termites through barriers of sand or cinders. J. Econ. Entomol. 50: 690-692.

8. Hadi, Y.S., M. Westin and E. Rasyid. 2005. Resistance of wood to termite attack. Forest Products Journal 55 (11): 318-325.

9. Mijinyawa, Y., S.O. Adesogan and O.G. Ogunkoya. 2006. A survey of roof failures in Oyo State of Nigeria. Journal of Building Appraisal 3 (1): 52-58.

10. Olanitori, L.M. 2006. Drying of woods for roof trusses in residential and commercial buildings. Faculty of Engineering, University of Port Harcourt, pp. 61-65.

11. Rizk, M.M., A.R. El-Sayed, A.M. Ali and S.A. Eraky. 1985. Flight activity and annual caste fluctuation of sand termite Psammotermes hybostoma (Desneux) in western desert-Egypt. Assuit. J. Agric. 16 (2): 137-148.

12. Smith, J. L. and M. K. Rust. 1990. Tunneling response and mortality of the western subterranean termite, Reticulitermes hesperus (Isoptera: Rhinotermitidae) to soil treated with insecticides. J. Econ. Entomol. 83: 13951401.

13. Tamashiro, M., J. R. Yates \& R. H. Beaus. 1987. The Formosan subterranean termite in Hawaii: problems and control, pp. 15- 22. In: M. Tamashiro and N.-Y. Su [eds.], Biology and control of the Formosan subterranean termite. College of Tropical Agriculture and Human Resources, Univ. of Hawaii, Honolulu, HI. 
تأثير تنوع البلاطات الخرسانية في منع الإصابة بالنمل الأبيض تحت الأرضي من النوع psammotermes hybostoma (Desneux)

$$
\begin{aligned}
& \text { حسن محمد أحمد على } \\
& \text { قسم بحوث ناخرات الاخشاب والنمل الابيض - معهر بحوث وقاية النباتات - الدقى - الجيزة }
\end{aligned}
$$

تم دراسة تأثير تتوع البلاطات الخراسانية في منع أو صد الإصابة بالنمل الأبيض تحت الأرضي من النوع لخألواح الخشبية بمحافظة أسوان خلال ثلاث سنوات متتالية ( 2009-2011 ). تم بناء ستة عشر بلاطة خرسانيه في مساحة مبنى

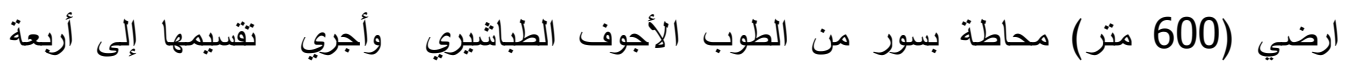
مجموعات حيث كانت مواد بناء المجموعة الأولى ممثلة في الرمل والاسمنت فقط بينما كانت بلاطات

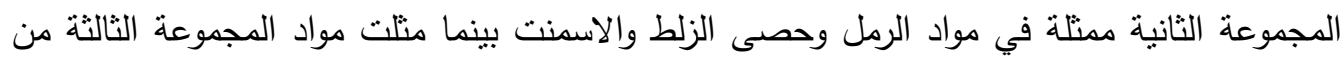

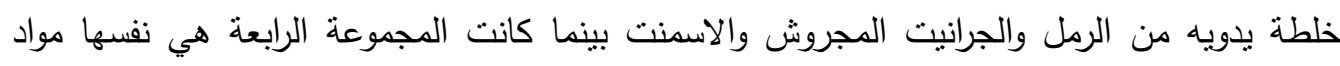
المجموعة الثالثة ولكن تم الخلط للخرسانة بواسطة الخلاط الميكانيكي ـ ومن خلال الفحص الذي اجري

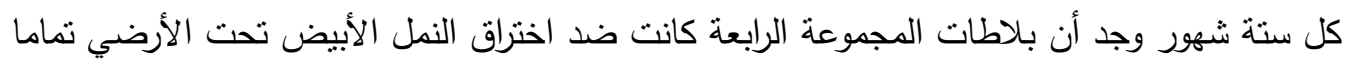
يليها بلاطات المجموعة الثالثة بنسبة اقل من 100\% في حين أظهرت بلاطات المجموعة الثانية

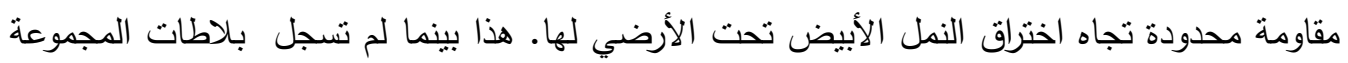

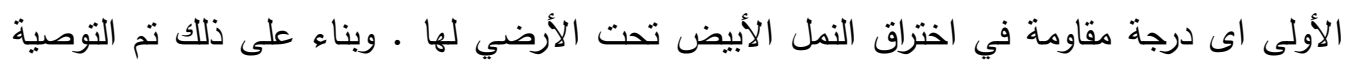

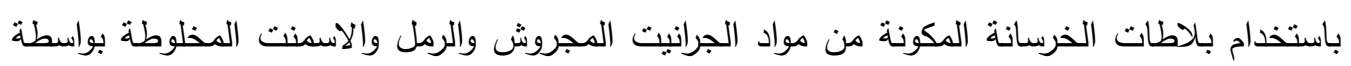

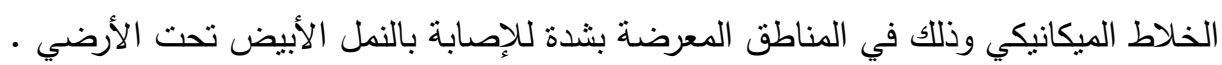

